\title{
Е.Н. Колокольцев
}

Московский государственный областной университет, 141014 г. Мытищи, Московская область, Российская Федерация

\section{Поэтика описаний в романе М.Ю. Лермонтова «Герой нашего времени» на уроках литературы}

\begin{abstract}
Аннотация. Целью исследования является актуализация на уроках литературы роли описаний в романе М.Ю. Лермонтова «Герой нашего времени» как важного конструктивного элемента повествования. Наиболее частой формой описания в романе являются описания природы и описания портретов действующих лиц. Описания нашли живой отзыв в литературоведении, литературной критике и в искусствознании, откликнувшемся на картины поэта-художника и иллюстрации к роману. Это закономерно привлекло внимание автора к исследованию трудов ученых, в поле зрения которых оказывались особенности повествовательной манеры Лермонтова. В повестях, составивших лермонтовский роман, описания выполняют важную композиционную роль: они сопровождают повествование, размышления героев и зачастую мотивируются автором. В статье освещается ряд приемов, которые позволят школьникам конкретизировать представления об описаниях в романе. Осознанному восприятию учащимися пейзажных описаний поможет составление плана, который отобразит пространственно-временную структуру повести «Бэла», представляющей собой и "путевые записки», и новеллу. Привлечение репродукций кавказских пейзажей Лермонтова, близких по объекту изображения словесным описаниям в романе, служит зримым эмоциональным подспорьем в постижении школьниками описаний природы. Обращение к психологическому портрету Печорина вызвало такой способ постижения особенностей его портрета, как составление стилистической карты, которая концентрирует внимание учеников на языковых средствах, позволяющих повествователю связать облик героя с предполагаемыми свойствами его характера. Тесно переплетаются пути изображения и слова в художественной иллюстрации, выполняющей функцию изобразительной речи и дающей пространственное изображение литературного произведения. Иллюстрация служит средством конкретизации представлений учеников о портретах действующих лиц, описаниях природы и связанных с ними сюжетных ситуациях. Способы осмысления художественного текста с широким привлечением произведений изобразительного искусства ведут школьников к познанию особенностей повествовательной манеры Лермонтова и служат их эстетическому развитию.
\end{abstract}

Ключевые слова: роман М.Ю. Лермонтова «Герой нашего времени», описания как элемент повествования, «путевые записки», пейзажные описания, портрет героя литературного произведения, сюжетные иллюстрации, произведения живописи на уроках литературы

\section{E.N. Kolokoltsev}

Moscow Region State University, Mytishi, Moscow Region, 141014, Russian Federation

\section{Poetics of descriptions in the novel "A Hero of Our Time" by M.Yu. Lermontov in Literature classes}

Abstract. The purpose of the study is to actualize the role of descriptions in the novel by $M$. Yu. Lermontov "A Hero of Our Time" as an important constructive element of the narrative. The most common form of description in the novel is the descriptions of nature and descriptions 
of the characters' portraits. The descriptions found a lively response in literature studies, literary criticism, in art criticism, which responded to the paintings of the poet-and-artist and illustrations for the novel. Naturally, it attracted the author's attention to the study of the works of those scholars, who viewed the features of Lermontov's narrative manner. In the stories that made up Lermontov's novel, descriptions play an important compositional role: they accompany the narrative, the thoughts of the characters, and they are often motivated by the author. The article highlights a number of techniques that will allow students to specify ideas about the descriptions in the novel. The students' comprehension of landscape descriptions can be supported by drawing up a plan that will reflect the spatial and time-line structure of the story "Bela", which represents both "travel notes" and the novelette. The use of reproductions of Lermontov's Caucasian landscapes, similar in the object image to its verbal descriptions in the novel, serves as a visible emotional aid in the nature descriptions comprehension by schoolchildren. Turning to Pechorin's psychological portrait caused such ways of discovery of his portrait features as drawing up a stylistic map that assists students to focus on linguistic means that the narrator uses to relate the hero image with his potential ingrain. The image and words are closely intertwined in the art print that performs the function of figure of speech and gives a spatial image to the piece of writing. The illustration serves as a means of specifying the students' perceptions of the characters' portraits, descriptions of nature and the related plot situations. Ways to comprehend a literary text with the wide involvement of works of art assist students to learn about the peculiarities of Lermontov's narrative manner and facilitate their aesthetic development.

Key words: M.Yu. Lermontov's novel "A Hero of Our Time", descriptions as an element of narration, "travel notes", landscape descriptions, the portrait of a character in a literary work, plot illustrations, works of painting in Literature lessons 